\title{
THE EFFECTS OF TUBAL LIGATION ON OVUM TRANSPORT IN RABBITS
}

\author{
D. G. SHARP, III AND D. L. BLACK \\ Laboratory for Reproductive Physiology, \\ Department of Veterinary and Animal Sciences, \\ University of Massachusetts, Amherst, Massachusetts 01002, U.S.A.
}

(Received 25th February 1974)

\begin{abstract}
Summary. Ovum transport was studied in rabbit oviducts ligated $18 \mathrm{hr}$ after mating in untreated and oestrogen-treated rabbits. Essentially all ova $(93.5 \%)$ were recovered from the sham-ligated oviducts up to $72 \mathrm{hr}$ post coitum (p.c.). Ovum recovery from all ligated oviducts averaged $46.7 \%$. Recovery of ova in oviducts ligated at the infundibulum and at the uterotubal junction was $100 \%$. It is likely, therefore, that ova were transported prematurely into the uterus from ligated oviducts. Ovum transport through sham-ligated oviducts was significantly retarded by a single injection of oestradiol cyclopentylpropionate ( 25 or $250 \mu \mathrm{g}$ ) but remained accelerated in ligated oviducts of oestrogentreated rabbits. The distension of ligated oviducts diminished by $60 \mathrm{hr}$ p.c. in untreated rabbits, but was maintained in oestrogen-treated rabbits. Ovum transport through distended oviducts may be accelerated by the passage of oviducal fluid into the uterus.
\end{abstract}

\section{INTRODUCTION}

The mechanism which regulates passage of ova from the oviducts into the uterus is poorly understood. Muscular contractions of the oviduct presumably play a major rôle in egg transport (Boling, 1969) but movement of oviducal fluids may also contribute to the uterine migration of tubal ova.

Black \& Asdell (1958) reported that ligation of the rabbit oviduct at the infundibulum resulted in fluid accumulation and marked distension of the oviduct. Black \& Asdell (1959) further demonstrated that the fluid disappeared from ligated oviducts by $60 \mathrm{hr}$ after mating. Similarly, Belvé \& McDonald (1968) reported that most of the oviducal secretions of sheep passed out of the tubal ostium early in the oestrous cycle. On Day 4, however, the time when ova usually enter the uterus, fluid flow through the uterotubal junction markedly increased.

Ovum transport can be enhanced (Burdick \& Whitney, 1938; Greenwald, 1957; Harper, 1964) or retarded (Burdick \& Pincus, 1935; Chang, 1966; Longley, Black \& Currie, 1967) with oestrogens, depending on dose and method of administration. Secretion of oviducal fluid is enhanced by oestrogens (Bishop, 1956; Greenwald, 1958; Mastroianni, Beer, Shah \& Clewe, 1961; 
Black, Crowley, Duby \& Spilman, 1968). Black \& Asdell (1959) also reported that oestrogen administration to rabbits with ligated oviducts resulted in maintenance of distension for more than $100 \mathrm{hr}$ p.c. It is possible that a functional relationship exists between oviducal fluid secretion and ovum transport. This project was designed to determine the effect of the distension produced by ligating the ovarian end of the rabbit oviduct on ovum transport in untreated, and oestrogen treated rabbits.

\section{MATERIALS AND METHODS}

Virgin Dutch belted does weighing 1.5 to $2.1 \mathrm{~kg}$ were used. Rabbits (six/group) were assigned to one of three treatment groups which received (1) corn oil $(0.2 \mathrm{ml})$, (2) $25 \mu \mathrm{g}$ oestradiol cyclopentylpropionate (OEGP) $/ 0.2 \mathrm{ml}$ corn oil, or (3) $250 \mu \mathrm{g}$ OECP $/ 0 \cdot 2 \mathrm{ml}$ corn oil, respectively, for each of five time periods. The injections were given subcutaneously immediately after the rabbits were mated. The does were anaesthetized with ether $18 \mathrm{hr}$ later and one oviduct in each rabbit was ligated at the infundibulum. The contralateral oviduct was handled in a like manner but was not ligated (sham-ligated).

At the five time periods after mating $(24,36,48,60$ and $72 \mathrm{hr})$, the does were killed by cervical dislocation and the lower abdominal viscera were exposed. All movement of the reproductive tract was stopped by freezing with isopentane chilled to about $-150^{\circ} \mathrm{G}$ in liquid nitrogen (Longley \& Black, 1968). When thawed, the oviducts were removed and carefully trimmed. Corpora lutea were counted for later comparison with the number of eggs found in the oviducts. The trimmed oviducts were fixed in acetic acid and formalin, dehydrated in graded alcohols, and cleared in benzyl benzoate according to the method of Orsini (1962). Observation of ova within the cleared oviducts was accomplished with a dissecting microscope. The average position of the eggs in each oviduct was calculated as a percentage of the distance from the ovarian end to the uterotubal junction. When the number of ova found was less than the number of corpora lutea counted, the missing eggs were considered to have travelled $100 \%$ of the distance through the oviduct for all groups.

Ligated oviducts were arbitrarily classified according to the amount of distension present; 0 , not distended; + , moderate distension; and ++ , severe distension.

To test whether identification of ova within distended oviducts was possible, one oviduct from each of four rabbits was ligated at the infundibulum and at the uterotubal junction. These oviducts were fixed and cleared as above.

The data were arranged in a split-plot design and tested for significant differences by analysis of variance.

\section{RESULTS}

There was no significant difference in ovum recovery from oestrogen-treated or control (vehicle only) sham-ligated oviducts over the five time periods. The average ovum recovery from sham-ligated (control or oestrogen-treated) oviducts was $93.5 \%$. Ovum recovery from the ligated oviducts, however, was 
significantly reduced (see Table 1 ). The average ovum recovery from ligated oviducts (control or oestrogen-treated) was $46.7 \%$. As can be seen in Textfig. 1, ovum recovery from sham-ligated oviducts changed little over the five time periods, while ovum recovery from ligated oviducts decreased sharply to a minimum $7 \cdot 1 \%$ recovery by $72 \mathrm{hr}$ after mating. The difference between these two linear trends was highly significant, indicating that ovum recovery from ligated oviducts became rapidly poorer as the time after mating increased.

Table 1. Number of ova recovered per treatment group from does with ligated and sham-ligated oviducts

\begin{tabular}{|c|c|c|c|c|c|c|}
\hline \multirow[b]{2}{*}{$\begin{array}{c}\text { Time } \\
\text { after } \\
\text { mating } \\
(h r)\end{array}$} & \multicolumn{2}{|c|}{ Vehicle only } & \multicolumn{2}{|c|}{$25 \mu \mathrm{g}$ Oestrogen } & \multicolumn{2}{|c|}{$250 \mu \mathrm{g}$ Oestrogen } \\
\hline & $\begin{array}{l}\text { Sham- } \\
\text { ligated }\end{array}$ & Ligated & $\begin{array}{l}\text { Sham- } \\
\text { ligated }\end{array}$ & Ligated & $\begin{array}{l}\text { Sham- } \\
\text { ligated }\end{array}$ & Ligated \\
\hline $\begin{array}{l}24 \\
36 \\
48 \\
60 \\
72\end{array}$ & $\begin{array}{l}16(20) \\
25(22) \\
25(25) \\
22(22) \\
20(28)\end{array}$ & $\begin{array}{r}17(23) \\
14(26) \\
13(25) \\
15(34) \\
5(33)\end{array}$ & $\begin{array}{l}23(24) \\
22(22) \\
21(20) \\
26(31) \\
27(26)\end{array}$ & $\begin{array}{r}19(22) \\
19(29) \\
11(22) \\
13(26) \\
0(24)\end{array}$ & $\begin{array}{l}16(18) \\
19(22) \\
21(33) \\
29(29) \\
19(23)\end{array}$ & $\begin{array}{r}19(29) \\
16(22) \\
11(26) \\
4(18) \\
2(32)\end{array}$ \\
\hline
\end{tabular}

Figures in parentheses represent the total number of corpora lutea/group.

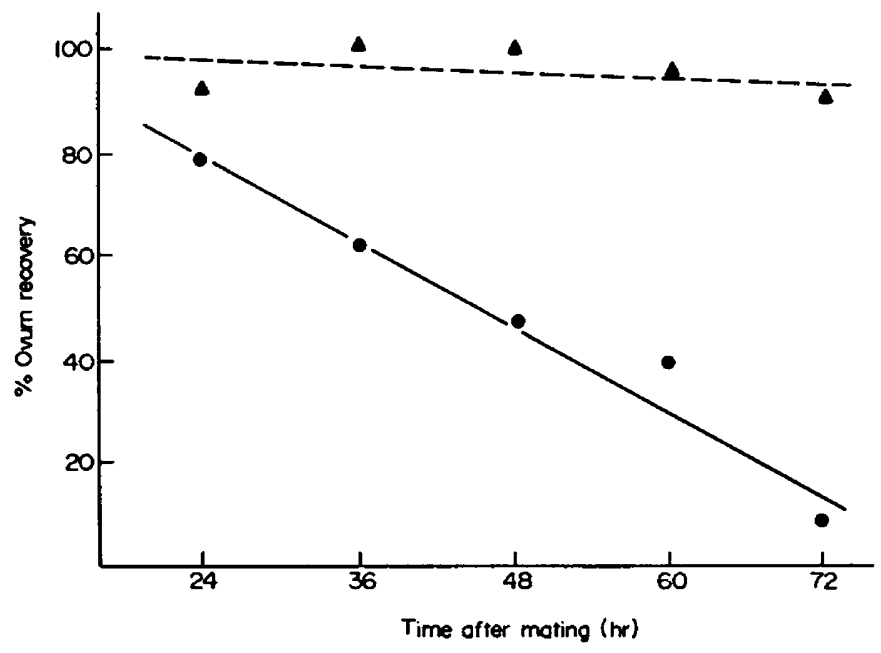

TExT-FIG. 1. Comparison of $\%$ ovum recovery from ligated $(\bullet)$ and sham-ligated $(\Delta)$ oviducts of rabbits. The regression line for sham-ligated oviducts did not change with time, but the difference between ligated and sham-ligated oviducts was highly significant $(P=0.01)$ over time.

Sixteen ova were found in the oviducts with two ligatures from four rabbits and sixteen corpora lutea were counted on the ovaries of these animals, showing that identification of ova within distended oviducts was possible. In contrast to distension produced in oviducts ligated only at the ovarian end, distension of the oviducts with two ligatures appeared to be more extensive and extended down the isthmus. In oviducts with one ligature, the diameter of the distended 
oviduct decreased in the region of the ampullary-isthmic junction and the isthmus was not markedly distended.

The average position of ova within sham-ligated oviducts advanced only slightly from 24 to $72 \mathrm{hr}$ after mating (see Table 2). By $72 \mathrm{hr}$ after mating, ova in sham-ligated control oviducts had travelled $78.1 \%$ of the distance to the uterus. Ovum transport through the distended oviducts, however, was apparently accelerated. The average position of ova in the ligated control oviducts (including missing ova-see 'Materials and Methods') was $93.8 \%$ of the oviducal length by $72 \mathrm{hr}$ p.c. (Table 2). The average position of the ova that remained in the distended oviducts changed little from 24 to $72 \mathrm{hr}$ and ova were not seen in the isthmus of the ligated oviducts.

Table 2. Position of ova in ligated and sham-ligated oviducts of vehicle- and oestrogen-treated rabbits

\begin{tabular}{|c|c|c|c|c|c|c|}
\hline \multirow{2}{*}{$\begin{array}{c}\text { Time } \\
\text { after } \\
\text { mating } \\
\text { (hr) }\end{array}$} & \multicolumn{2}{|c|}{ Vehicle only } & \multicolumn{2}{|c|}{$25 \mu \mathrm{g}$ Oestrogen } & \multicolumn{2}{|c|}{$250 \mu \mathrm{g}$ Oestrogen } \\
\hline & $\begin{array}{l}\text { Sham- } \\
\text { ligated }\end{array}$ & Ligated & $\begin{array}{l}\text { Sham- } \\
\text { ligated }\end{array}$ & Ligated & $\begin{array}{l}\text { Sham- } \\
\text { ligated }\end{array}$ & Ligated \\
\hline $\begin{array}{l}24 \\
36 \\
48 \\
60 \\
72\end{array}$ & $\begin{array}{l}60 \cdot 1 \pm 6 \cdot 7 \\
71 \cdot 0 \pm 5 \cdot 2 \\
72 \cdot 1 \pm 2 \cdot 5 \\
72 \cdot 8 \pm 3 \cdot 4 \\
78 \cdot 1 \pm 5 \cdot 2\end{array}$ & $\begin{array}{l}29 \cdot 9 \pm 2 \cdot 0 \\
71 \cdot 6 \pm 10 \cdot 2 \\
69 \cdot 1 \pm 7 \cdot 7 \\
74 \cdot 1 \pm 13 \cdot 6 \\
93.8 \pm 6 \cdot 2\end{array}$ & $\begin{array}{l}51 \cdot 1 \pm 3 \cdot 0 \\
49 \cdot 5 \pm 1 \cdot 6 \\
53 \cdot 3 \pm 5 \cdot 1 \\
59 \cdot 9 \pm 7 \cdot 3 \\
55 \cdot 3 \pm 4 \cdot 9\end{array}$ & $\begin{array}{r}47 \cdot 8 \pm 7 \cdot 8 \\
59 \cdot 4 \pm 11 \cdot 3 \\
67 \cdot 7 \pm 11 \cdot 7 \\
66 \cdot 6 \pm 12 \cdot 1 \\
100 \cdot 0 \pm 0 \cdot 0\end{array}$ & $\begin{array}{l}53 \cdot 4 \pm 4 \cdot 3 \\
58 \cdot 5 \pm 4 \cdot 5 \\
56 \cdot 8 \pm 3 \cdot 8 \\
43 \cdot 3 \pm 2 \cdot 2 \\
60 \cdot 1 \pm 4 \cdot 5\end{array}$ & $\begin{array}{l}57 \cdot 1 \pm 8 \cdot 5 \\
61 \cdot 5 \pm 8 \cdot 8 \\
71 \cdot 3 \pm 12 \cdot 0 \\
73 \cdot 3 \pm 15 \cdot 9 \\
91 \cdot 3 \pm 8 \cdot 7\end{array}$ \\
\hline
\end{tabular}

Values are expressed as a mean percentage \pm S.E. of the distance from the infundibulum to the uterotubal junction. The oviducts of six does were examined at each time for each treatment group.

Injection of 25 or $250 \mu \mathrm{g}$ OECP immediately after mating retarded ovum transport through the sham-ligated but not the ligated oviducts (Table 2). By $72 \mathrm{hr}$ p.c., the ova in the sham-ligated oviducts had only travelled 55.3 and $60.1 \%$ of the distance to the uterus in rabbits receiving 25 and $250 \mu \mathrm{g}$ OECP respectively. The average position of ova (including missing ova) in the ligated oviducts of rabbits receiving 25 and $250 \mu$ OECP was 100.0 and $91.3 \%$ respectively at $72 \mathrm{hr}$ p.c. (Table 2 ). The distension of the ligated control oviducts diminished by $60 \mathrm{hr}$ p.c. $(0)$ but was still present $(++)$ in the ligated oestrogen-treated oviducts at $72 \mathrm{hr} p . c$.

\section{DISGUSSION}

Ovum recovery from sham-ligated oviducts (control or oestrogen-treated) was high for all five time intervals studied. The time required to transport tubal ova to the uterus in rabbits following mating is 72 to $75 \mathrm{hr}$ (Gilchrist \& Pincus, 1932). At $72 \mathrm{hr}$ after mating, ovum recovery from the sham-ligated oviducts was decreased, but not significantly. Ovum recovery from the ligated oviducts was high initially, but dropped rapidly by $72 \mathrm{hr}$ p.c. The low recovery rate of ova from the ligated oviducts might have resulted from: (1) failure of ova to enter the oviducts, or (2) passage of ova through the isthmus to the uterus. The former is unlikely since recovery rate in contralateral oviducts (sham- 
ligated) was high for all groups. Identification of ova within distended cleared oviducts was possible, therefore the low percentage of ova observed in the ligated oviducts probably indicates passage of the ova into the uterus. The fact that some ova remained in the ligated oviducts suggests that movement of ova into the uterus was erratic.

In this report, the distension of oviducts ligated at the ovarian end generally did not extend to the isthmus. Oviducts ligated at both ends, however, were distended at the ampulla and the isthmus. This suggests that although fluid accumulated and distended the ampulla in oviducts with one ligature, some fluid escaped into the uterus. It seems reasonable that such a flow of fluid might occur sporadically and could account for the apparently erratic movement of ova into the uterus. By $72 \mathrm{hr}$ after mating, only one of twelve oestrogen-treated ligated oviducts contained ova (Table 1). Although transport of ova was retarded in the sham-ligated oviducts of oestrogen-treated rabbits, the low recovery of ova from the ligated oviducts suggests that oestrogen did not block the movement of ova out of the ligated oviducts.

The observation that the oviducts of oestrogen-treated ligated rabbits were still showing full distension when distension of the control, ligated oviducts had subsided is in agreement with the report of Black \& Asdell (1959).

Both the low and high doses of OECP significantly retarded ovum transport through sham-ligated oviducts. Burdick, Whitney \& Pincus (1937) reported 'tube-locking' of ova in mice with moderate doses of oestrogen. The retention of ova in oestrogen-treated oviducts has been reported by many workers (Noyes, Adams \& WaIton, 1959; Greenwald, 1961; Longley et al., 1967). Oestrogens in high doses have, however, been reported to accelerate ovum transport according to many workers (Whitney \& Burdick, 1939; Greenwald, 1957; Harper, 1964). This contrasts with the results with the high dose of OECP used here which was similar to the dose employed by Greenwald (1957).

The low numbers of ova found in the distended oviducts suggests that the ova had been rapidly transported to the uterus. The mechanism by which this might be accomplished is unknown, but the following hypothesis is offered. The pressure which builds up in the distended oviduct may become great enough to overcome the isthmic resistance to fluid flow. When this happens, fluid passes into the uterus carrying eggs with it. In oestrogen-treated oviducts, the mechanism which prevents passage of ova to the uterus may be prolonged in its action. This is in agreement with the present observations and earlier findings (Black \& Asdell, 1959; Hafez \& Black, 1969) that oestrogen prolongs the distension of ligated oviducts. Accelerated transport of ova in ligated oestrogen-treated oviducts could still be explained by this hypothesis. Kurzrik, Wilson \& Birnberge (1953) suggested that the flow of fluid into the uterus aids transport of ova into the uterus. The transport of ova into the uterus from distended oviducts, though much exaggerated, may be attributed to a mechanism similar to the normal transport process

\section{REFERENCES}

Belvé, H. R. \& McDonald, M. (1968) Directional flow of Fallopian tube secretion in the Romney ewe. F. Reprod. Fert. 15, 357-364. 
Bishop, D. W. (1956) Active secretion of the rabbit oviduct. Am. F. Physiol. 187, 347-352.

Black, D. L. \& Asdell, S. A. (1958) Transport through the rabbit oviduct. Am. F. Physiol. 192, 63-68.

Black, D. L. \& AsDell, S. A. (1959) Mechanism controlling entry of ova into the rabbit uterus. $A m$. $\mathcal{J}$. Physiol. 197, 1275-1278.

Black, D. L., Growley, L. V., Duby, R. T. \& Spilman, C. H. (1968) Oviduct secretion in the ewe and the effect of oviduct fluid on oxygen uptake by ram spermatozoa in vitro. 7 . Reprod. Fert. $15,127-130$.

Boling, J. L. (1969) Endocrinology of oviductal musculature. In The Mammalian Oviduct, pp. 163-181. Eds. E. S. E. Hafez and R. J. Blandau. University of Chicago Press.

Burdick, H. O. \& Pincus, G. (1935) The effect of oestrin injections upon the developing ova of mice and rabbits. Am. J. Physiol. 111, 201-208.

Burdick, H. O. \& Whitney, R. (1938) Fate of ova accelerated in their rate of passage through the Fallopian tube of mice by massive injections of progynon-B. Endocrinology, 22, 631-638.

Burdick, H. O., Whitney, R. \& Pincus, G. (1937) The fate of mouse ova "tube-locked" by injections of oestrogenic substances. Anat. Rec. 67, 513-520.

Chang, M. C. (1966) Transport of eggs from the Fallopian tube to the uterus as a function of oestrogen. Nature, Lond. 212, 1048-1049.

Gilchrist, F. \& Pincus, G. (1932) Living rat eggs. Anat. Rec. 54, 275.

Greenwald, G. S. (1957) Interruption of pregnancy in the rabbit by the administration of estrogen. 7. exp. Zool. 135, 461-479.

Greenwald, G. S. (1958) Endocrine regulation of the secretion of mucin in the tubal epithelium of the rabbit. Anat. Rec. 130, 477-496.

Greenwald, G. S. (1961) A study of the transport of ova through the rabbit oviduct. Fert. Steril. $12,80-95$.

Hafez, E. S. E. \& Br.ack, D. L. (1969) The mammalian uterotubal junction. In The Mammalian Oviduct, p. 114. Eds. E. S. E. Hafez and R. J. Blandau. University of Chicago Press.

HARPER, M. J. K. (1964) The effects of constant doses of estrogen and progesterone on the transport of artificial eggs through the reproductive tract of ovariectomized rabbits. $\mathbf{F}$. Endocr. 30, 1-19.

Kurzrik, R., Wilson, L. \& Birnberge, O. (1953) Follicular fluid, its possible role in human fertility and sterility. Fert. Steril. 4, 479-494.

Longley, W. J. \& Black, D. L. (1968) Comparison of methods for locating ova in the oviduct of the rabbit. 7. Reprod. Fert. 16, 69-72.

Longley, W. J., Black, D. L. \& Gurrie, G. N. (1967) The influence of the autonomic nervous system and ovarian hormones on ovum transport in the rabbit. Fedn Proc. Fedn Am. Socs exp. Biol. 26, 1557.

Mastrolanni, L., Jr, Beer, F., Shah, U. \& Clewe, T. (1961) Endocrine regulation of oviduct secretion in the rabbit. Endocrinology, 68, 92-100.

Noyes, R. W., Adams, G. A. \& Walton, A. (1959) The transport of ova in relation to the dosage of oestrogen in ovariectomized rats. F. Endocr. 18, 108-117.

Orsins, M. W. (1962) Techniques of preparation, study and photography of benzyl-benzoate cleared material for embryological studies. F. Reprod. Fert. 3, 283-287.

Whitney, R. \& BuRDick, H. O. (1939) Effect of massive doses of an estrogen on ova transport in ovariectomized mice. Endocrinology, 24, 45-49. 